\title{
KOMUNIKASI PEMBANGUNAN MELALUI MUSYAWARAH RENCANA PEMBANGUNAN (MUSRENBANG) KABUPATEN ACEH UTARA
}

\author{
Jamal Mildad \\ Program Studi Ilmu Komunikasi, Universitas Teuku Umar \\ Email : jamalmildad@yahoo.com
}

\begin{abstract}
This study aims to find out the government commucation system throght Musrenbang (Musyawarah Rencana Pembangunan - Development Plan Discussion) in the devolopment north Aceh community's religiosity. The data were collected throght intensive imnterviews whit related figures, such as the head of North Aceh Bappeda, non-government organization leaders, north Aceh Community leaders, as well as the head of Ulama consultation Council (Majelis Permusyawartan Ulama) - MPU, who also is religious leader in North Aceh Regency. Data were also colleted through field observation. The study also revealed that the government communicates primerly (directly) with society through advice conveyed through Musrenbang, than the government communicates secondarily (indirectly) through mass media. The communicator of relegion to north Aceh society is the ulama, subdistrict and village personnels, $M P U$, religious and traditional figure. The government is facilitator for society's communication. The advice given are the elimination of vices, the upholding of Islamic law, the mastery of religious studies, and the strengthening of family. The result of north Aceh gavernment and society communication is not yet optimal. The quality of religion life as well as the infrastructure to increase this quality is not yet sufficient as society has'nt utilized the mosque optimally. Religious teaching as value is not yet understood, internalized, and acted upon by society in daily life. Negative and deviant behavior, far from religious, normative, and ethical injuctions, often occur. The problem above is due to stumbling blocks such as the weak human resource of development communicator. The reason is the limitation of fund for religious development be it in the physical aspects as well as the lack of society's role in development.
\end{abstract}

Keywords: Government Commucation, Development Plan Discussion, and Mass Media

\section{PENDAhUluan}

Pada prinsipnya pembangunan bertujuan melakukan perubahan dari satu keadaan menuju keadaan lain yang lebih baik, lebih berkualitas dan lebih maju. Perubahan yang dikehendaki dalam pembanguan tentunya perubahan kearah yang lebih baik, lebih berkualitas dan lebih maju. Perubahan yang dikehendaki dalam pembangunan tentunya perubahan ke arah yang lebih baik dan sempurna atau lebih maju dari keadaan yang sebelumnya. Pemerintah dalam suatu negara tidak lain adalah untuk mewujudkan pembangunan baik secara fisik maupun nonfisik. Hal itu berarti bahwa pembangunan proses, menghendaki penekanannya pada keselarasan antara aspek kemajuan lahiriah dan kepuasan bathiniah atau jasmani dan rohaniyah, aspek yang nampak dengan mata pengliahtan dan tidak nampak dengan mata penglihatan. Sejalan dengan hal tersebut, Kursyid Ahmad menempatkan pembangunan sumber daya inani sebagai tujuan pertama dari kebijakan pembangunan. Dengan demikian harus diupayakan membangkitkan sikap dan apresiasi yang benar, pengembagan watak dan kepribadian, pendidikan dan latihan yang menghasilkan keterampilan, pengembangan ilmu dan riset serta peningkatan partisipasi.

Selaras dengan cita-cita good gavernmance, manajemen keuangan daerah setidaknya menganut prinsip transparansi dan akuntabiitas. Managemen keuangan daerah dapat dikatakan transparan ketika terdapat keterbukaan dalam setiap proses anggaran. Transparansi yang dituntut ialah proses awal untuk keterlibatan publik terhadap anggaran pemerintah. Dalam arti lain masyarakat mempunyai hak dan akses yang sama untuk mengetahui berjalannya sekurang-kurang tiga proses, proses penganggaran, pelaksanaan serta pengawasan. Oleh karen itu untuk 
mewujudkan pengelolaan keuangan daerah yang transparan dan akuntabel, suatu sistem manajemen yang baik, juga sistem manajamen komunikasi yang baik.

Wilbur Schramm menyatakan bahwa komunikasi dan masyarakat bagaikan dua kata kembar yang tidak dapat dipisahkan satu sama lain, tanpa adanya proses komunikasi, maka tidak mungkin masyarakat terbentuk, sebaliknya tanpa masyarakat maka manusia tidak mungkin mengembangkan komunikasi. Setiap komunikator memiliki strategi komunikasi yang berbeda dalam mencapai tujuan komunikasi, namun pada hakikatnya semua orang memiliki tujuan yang sama yakni untuk menciptakan perobahan sikap pada diri khalayak atau komunikan (audience). Perubahan yang diharapkan yakni pada tingkat kognitif, afektif dan psikomotorik.

Berdasarkan pengamatan para ahli menemukan fungsi komunikasi yang berbeda antara satu dengan lainnya. Misalnya Thomas M. Scheidel mengemukakan bahwa kita berkomunikasi terutama untuk mendukung identitas diri, membangun kontak sosial dan mempengaruhi orang lain dalam berfikir dan berperilaku sesuai dengan yang kita inginkan. Sementara Rudolf F. Verderber mengemukakan bahwa komunikasi mempunyai dua fungsi yakni fungsi sosial dan fungsi pengambilan keputusan.

Efektifitas komunikasi jika dibangun atas dasar kesamaan akan mudah untuk mencapai suatu keberhasilan antara komunikator dengan komunikan, begitu pula terjadi pada pemerintah kabupaten Aceh Utara dalam melakukan komunikasi terhadap masyarakat.

Inti dari pembangunan adalah melakukan perubahan dari suatu keadaan ke arah keadaan yang lebih baik, lebih berkualitas serta lebih maju. Jika melihat kepada Undang-undang nomor 32 Tahun 2004 tentang pemerintahan daerah, disana dinyatakan bahwa salah satu urusan wajib yang menjadi kewanengan pemrintah daerah Kabupaten dan Kota yaitu Perencanaan dan Pengendalian Pembangunan, hal juga ditegaskan oleh Undang-undang No. 25 Tahun 2004 tentang sistem perencanaan pebangunan nasional.

Berdasarkan Undang-undang No. 32 Tahun 2004 Tentang Pemerintahan Daerah khususnya pada pasal 14 disebutkan bahwa diantara urusan wajib yang menjadi kewenangan pemerintah untuk kabupaten dan kota adalah perencanaan dan pengendalian pembangunan. Dalam merumuskan perencanaan dan mengendalikan pembangunan di daerah salah satu pilar yang merupakan faktor pendukung terwujudnya masyarakat Indonesia yang damai, demokratis, berkeadilan, berdaya saing, maju dan sejahtera, dalam wadah Negara Kesatuan Republik Indonesia. Cita-cita pembanguna tersebut baru akan dapat kita wujudkan dan capai salah satunya dengan membangun komunikasi serta musyawarah.

Musyawarah Perencanaan Pembangunan (Musrenbang) telah menjadi istiah populer dalam satu sistem pemerintahan. Musrenbag seringkali belum mencerminkan semangat musyawarah yang bersifat komunikasi dialog partisipatif, belum dapat menjadi ajang yang bersahabat semua elemen pemerintah dan masyarkat dalam mewujudkan program prioritas dalam pembangunan. Kemiskinan dan kesejahtrean menjadi persoalan utama dalam masyarakat masih menjadi perbincangan utama yang patut menjadi perhatian. .

Bila merujuk kepada teori yang dikemukakan Wilson dan Rosenfeld bahwa komunikasi antara pemrakarsa perubahan (variable) serta komponen yang memegang peranan (position maker) harus dilakukan secara intensif. Kepercayaan masyarakat akan menjadi lemah. Oleh karena itu untuk mengelola perubahan dibutuhkan upaya yang keras demi menjamin lancarnya komunikasi yang efektif antara agen (agent of change) dengan berbagai pihak yang mampu mengkonsolidasikan perubahan tersebut sebagaimana yang diharapkan. Ini artinya kendatipun kemajuan teknologi informasi dan komunikasi demikian pesat belum mampu memberikan kontribusi yang berarti dalam pencapaian pembangunan, jika sistem komunikasi pembangunan masih saja bersifat tradisional.

\section{METODE PENELITIAN}

Jenis penelitian yang dilakukan pada penelitian ini adalah penelitian kualitatif dengan pendekatan deskriptif kualitatif. Penelitian kualitatif menghasilkan uraian berupa kata - kata tertulis atau lisan dari perilaku aktor yang dapat diamati dalam suatu situasi sosial. 
Dalam menafsirkan data atas makna perilaku informan maka digunakan penafsiran fenomenologik dengan pola maksud tujuan dan pemaknaan. Hal ini sebagaimana pendapat Bogdan dan Biklen "Researches in the phenomenologichal mode attemp to understand the meaning of events ordinary people in particular situations.

Adapun inti dari penelitian kualitatif adalah sampainya temuan peneliti terhadap makna perilaku tema budaya yang merupakan alasan seseorang atau kelompok dalam melakukan sesuatu perilaku sesuai latar sosial.

Pengambilan informan kunci dalam penelitian ini dilakukan dengan menggunakan teknik sampling purposif (Purposive Sampling). Maksudnya adalah teknik ini mencakup orang-orang yang diseleksi atas dasar kriteria-kriteria tertentu yang dibuat periset berdasarkan tujuan riset, sedangkan orang-orang dalam populasi yang tidak sesuai dengan kriteria tersebut tidak dijadikan sampel. Kreteria tertentu tersebut diharapkan memilki informsi yang akurat.

Berdasarkan argumentasi di atas, periset memilih informan : (1) dengan kriteria memiliki wewenang dalam pembahasan Musrenbang di Kabupaten Utara, (2) pernah mengikuti pelatihan terutama menyangkut dengan penetapan regulasi dan teknis serta mekanismen pelaksanaan Musrenbang. Informan tersebut adalah Kepala Bappeda, serta tokoh masyarakat.

\section{HASIL DAN PEMBAHASAN}

Undang - undang no 32 Tahun 2004 tentang Pemerintahan Daerah merupakan kerangka dasar otonomi daerah yang salah satunya mengamanatkan dilaksanakannya perencanaan pembangunan dari bawah secara partisipatif. Payung hukum dalam pelaksanaan Musrenbang diatur dalam Undang-undang Nomor 25 Tahun 2004 sistem perencanaan pembangunan Nasional yang secara teknis diatur dengan Surat Edaran Menteri yang setiap tahun menerbitkan petunjuk teknik tata cara penyelenggaraan Musrenbang.

Menurut Undang-Undang Nomor 25 Tahun 2004, Musyawarah Perencanaan Pembagunan yang selanjutnya disingkat Musrenbang adalah forum antar pelaku dalam rangka menyusun rencanan pembanguna nasionla serta rencana pembangunan daerah. Dalam forum ini pemerintah dan masyarakat bersama-sama merumuskan prioritas program yang akan dianggarkan. Prosedur mengenai Musrenbang selanjutnya diatur dalam Surat Edaran Menteri dalam negeri Nomor 640/751/SJ Tanggal 12 Maret 2009 tentang Penyusunan RKPD (Rencana Kerja Pemerintah Daerah) dan Tahun 2010. Berdasarkan Surat Edaran Menteri tersebut, untuk menyusun Rencana Kerja Pemerintah Daerah (RKPD) yang berfungsi sebagai dokumen perencanaan tahunan, pemerintah daerah perlu menyelenggarakan forum Musyaarah Perencanaan Pembangunan (Musrenbang) secara berjenjang, mulai dari tingkat desa/kelurahan, kecamatan, kabupaten/kota hingga tingkat provinsi, termasuk penyelenggaraan Forum Satuan Kerja Perangkat Daerah (Forum SKPD) ditingkat provinsi, kabupaten dan kota. Pada prinsipnya harus ditanamkan pada masyarakat, bahwa Musrenbang Gampong, Kecamatan, maupun Kabupaten tidaklah dalam upaya membuat Daftar Panjang (Long-List) Usulan Kegiatan Pembangunan yang merupakan Daftar Keinginan yang tidak terukur dengan kemampuan pembiayaan.

Dari segi proses, maka nampak bahwa Surat Edaran ini telah melibatkan warga baik sebagai peserta maupun sebagai pengambil keputusan. Peran warga dalam proses Musrenbang ini sangat penting kaena berdasarkan UU No. 25/2004, Musrenbang merupakan sumber utama dokumen perencanaan baik jangka panjang, jangka menengah, maupun tahunan. Sedangkan dokumen perencanaan tahunan merupakan rujukan utama dalam mengalokasikan anggaran. Dengan demikian maka Musrenbang dapat dikatakan sebagai salah satu forum partisipatif bagi warga untuk membicarakan perencanaan dan penganggaran di tingkat daerah.

Mengingat pentingnya Musrenbang dalam Sistem Perencanaan Pembangunan, maka mekanismenya telah diatur secara efektif dan efisien, mekanisme itu sendiri menyangkut dua hal, yaitu: siapa yang terlihat (siapa pelaku pembangunan / stakeholder) dalam Musrembang dan bagaimana proses (jalannya) Musrenbang, baik ditingkat Gampong (Desa), Kecamatan maupun Kabupaten. 
Mekanisme Musrenbang Kabupaten berdasarkan Surat Edaran Menteri Dalam Negeri, dilaksanakan dengan agenda sebagai berikut :

\section{A. Tahap Persiapan :}

Kepala Bappeda menetapkan Tim Penyelenggara Musrenbang Kabupaten.

Tim penyelenggara melakukan hal-hal sebagai berikut :

a. Mengkompilasi kegiatan prioritas pembangunan dari Forum SKPD dan Musrenbang Kecamatan.

b. Menyusun jadwal dan agenda Musrenbang.

c. Mengumumkan secara terbuka jadwal, agenda, dan tempat Musrenbang Kabupaten minimal 7 hari sebelum acara Musrenbanng dilakukan, agar peserta bisa segera melakukan pendaftaran dan atau diundang.

d. Membuka pendaftaran dan atau mengundang calon peserta Musrenbang Kabupaten, baik delegasi dari Kecamatan maupun dari Forum SKPD.

e. Menyiapkan peralatan dan bahan/materi serta notulen untuk Musrenbang Kabupaten.

\section{B. Tahap Pelaksanaan :}

1. Pemaparan rancangan RKPD dan kegiatan prioritas pembangunan serta plafon anggaran yang dikeluarkan oleh Bupati dan Kepala Bappeda.

2. Pemaparan hasil kompilasi kegiatan prioritas pembangunan dari Forum SKPD berikut pendanaannya oleh ketua tim penyelenggara.

3. Verifikasi hasil kompilasi oleh kepala SKPD, delegasi Kecamatan dan delegasi Forum SKPD.

4. Pemaparan kepala SKPD tentang Rancangan Renja-SKPD (terutama SKPD yang mengemban fungsi pelayanan dasar dan yang menjadi prioritas pembangunan Kabupaten) yang meliputi :

a. Isu-isu strategis SKPD yang berasal dari Renstra Kapupaten dan Renstra-SKPD/ Unit Kerja.

b. Tujuan, indikatr pencapaian dan kegiatan prioritas pembangunan yang akan dimuat dalam Renja-SKPD.

c. Penyampaian perkiraan kemampuan pendanaan terutama dana yang berasal APBD Kabupaten, APBD Provinsi, APBN dan sumber dana lainnya.

d. Membahas kriteria untuk menentukan kegiatan prioritas pembangunan tahun berikutnya.

e. Membagi peserta ke dalam beberapa kelompok berdasarkan fungsi/SKPD.

f. Menetapkan kegiatan priorits sesuai dengan besaran plafon anggaran APBD setempat serta yanga akan diusulkan untuk dibiayai dari sumber APBD Provinsi, APBN maupun sumber dana lainnya.

g. Membahas pemutakhiran Rancangan RKPD Kabupaten.

h. Membahas kebijakan pendukung implementasi program/kegiatan tahun berikutnya.

\section{Keluaran.}

Keluaran dari pelaksanaan Musrenbang Kabupaten adalah kesepakatan tentang rumusan yang menjadi masukan utama untuk memutkhirkan rancangan RKPD dan rancangan Renja-SKPD, yang meliputi :

1. Penetapan arah kebijakan, prioritas pembangunan, dan plafon/pagu dana balik berdasarkan fungsi/SKPD.

2. Daftar kegiatan prioritas yang sudah dipilah berdasarkan sumber pembiayaan dari APBD Kabupaten; APBD Provinsi, APBN dan sumber dana lainnya.

3. Daftar usulan kebijakan/regulasi pada tingkat pemerintah Kabupaten, Provinsi, dan /atau Pusat.

4. Rancangan pendanaan untuk Alokasi Dana Desa. 


\section{Peserta}

peserta Musrenbang Kabupaten adalah delegasi dari Musrenbang Kecamatan dan delegasi dari Forum SKPD.

\section{E. Narasumber}

Yang menjadi narasumbernya adalah Satuan Kerja Perangkat Daerah Kabupaten, DPRD, LSM, Perguruan Tinggi, Perwakilan Bappeda Provinsi, Tim Penyusun RKPD, Tim Penyusun Renja-SKPD Panitia/Tim Anggaran Eksekutif maupun DPRD.

\section{F. Penyampaian Hasil Musrenbang Kabupaten}

Setelah hasil Musrenbang Kabupaten disepakati oleh peserta, maka pemerintah Kabupaten menyampaikan hasilnya kepada :

1. DPRD setempat.

2. Masing-masing Satuan Kerja Perangkat Daerah Kabupaten.

3. Tim Penyusun Program Tahunan Daerah dan RAPBD.

4. Kecamatan.

5. Delegasi dari Musrenbang Kecamatan dan Forum SKPD.

\section{G. Pasca-Musrenbang Kabupaten}

Berbagai hal yang perlu dilakukan balik oleh pemerintah daerah pada Pasca-Musrenbang adalah sebagai berikut :

1. Penyususnan RKPD, dengan penjelasan sebagai berikut:

a. Bappeda menyediakan informasi kepada masyarakat maupun SKPD tentang hasil akhir RKPD. Bila terdapat perbedaan antara hasil Musrenbang Tahunan Kabupaten dengan RKPD, maka Bappeda memberitahukan alasan-alasannya.

b. Bappeda menyampaikan aspirasi dari masyarakat maupun SKPD kepada Bupati dan DPRD, terutama keberatan-keberatan mengenai tidak tertampungnya kegiatan-kegiatan yang berasal dari Musrenbang Kabupaten dalam rancangan RKPD.

2. Bappeda menyampaikan rancangan RKPD kepada pemerintah Provimsi, Bappeda Provinsi sebagai bahan rujukan bagi pelaksanaan Forum SKPD Provinsi dan Musrenbang Provinsi.

3. Penyusunan arah kebijakan, strategi, dan plafon APBD, dengan menggunakan RKPD sebagai rujukan utamanya.

4. Penyusunan Rencana Kerja dan Anggaran Satuan Kerja Perangkat Daerah (RKASKPD) oleh SKPD.

5. Pembahasan dan penetapan APBD, dimana Bappeda membantu DPRD untuk menyelenggarakan konsultasi publik tentang RAPBD sesuai ketentuan yang berlaku.

6. Pelaksanaan, monitoring, dan evaluasi program, dengan penjelasan sebagai berikut :

a. Bappeda memberikan informasi kepada masyarakat tentang pelaksanaan program/kegiatan, baik yang bersumber dari APBD maupun yang bersumber dari non-APBD berikut besaran Platformnya. Informasi ini memuat program/kegiatan berdasarkan SKPD dan berdasarkan lokasi (kecamatan dan desa/kelurahan).

b. Bappeda mengendalikan pelaksanaan kegiatan agar tetap sesuai dengan rencana.

c. Bappeda menanggapi keluhan mengenai pelaksanaan kegiatan dan melakukan evaluasi mengenai kepuasan masyarakat terhadap kegiatan pembangunan yang sedang dan telah dijalankan.

d. Bappeda memberikan umpan balik/masukan pada perencanaan selanjutnya.

7. Perubahan APBD. Setiap perubahan anggaran yang mempunyai konsekwensi kegiatan baru maka perlu melibatkan kembali SKPD dan delegasi dari kecamatan serta Forum SKPD dalam perumusan kegiatan dan proses pengalokasian anggarannya.

Selanjutnya proses pelaksanaan Musrenbang Kabupaten Aceh Utara dinilai berdasarkan keputusan Mendagri Nomor 050-187/Kep/Bangda/2007 Tahun 2007 tentag Pedoman Penilaian 
dan Evaluasi Pelaksanaan Penyelenggaraan Musyawarah Perencanaan Pembangunan (Musrenbang). Pedoman ini disusun dengan maksud untuk menilai dan mengevaluasi secara cepat, praktis dan sistematis pelaksanaan penyelenggaraan Musrenbang Provinsi dan Kabupaten sebagai bagian dari proses penyusunan Rencana Kerja Pemerintah Daerah (RKPD) dan Anggaran Pendapatan dan Belanja Daerah (APBD) sebagaimana diamanatkan dalam Undang-Undang Nomor 25 tahun 2004 tentang Sistem Perencanaan Pembangunan Nasional (SPPN) dan UndangUndang Nomor 32 tahun 2004 tentang Pemerintah Daerah.

Sebagai salah satu instrumen penilaiaan dan evaluasi, pedoman ditujukan untuk memberikan suatu penilaian dalam proses penyelenggaraan Musrenbang, serta mengidentifikasi kekuatan dan kelemahan berbagai aspek seperti kualitas Musrenbang, mulai dari proses persiapan sampai dengan berakhirnya penyelenggaraan Musrenbang. Penilaian didasarkan atas ketersediaan berbagai aspek pelaksanaan Musrenbang. Penilaian Ya diberikan skor 1 sementara penilaian TIDAK diberikan skor 0 perolehan skor selanjutnya dijumlahkan untuk mendapatkan kumulatif skor dan dibandingkan dengan skor idelal untuk mengetahui persentase pencapaiannya. Sebagai perbandingannya.

Tabel 3. 1 Data Musrenbang Kabupaten Aceh Utara

\begin{tabular}{cll}
\hline No & \multicolumn{1}{c}{ Pertanyanan } & \multicolumn{1}{c}{ Jawaban } \\
\hline 1 & Nama Kabupaten & Aceh Utara \\
2 & Jumlah Penduduk Kabupaten & 515.974 Jiwa \\
& Dokumen perencanaan yang dimiliki daerah & \\
3 & RPJPD & Ada \\
4 & RPJMD & Ada \\
5 & RENSTRA SKPD & Ada \\
7 & Tempat Pelaksanaan & Bappeda Kabupaten Aceh Utara \\
8 & Waktu pelaksanaan (hari dan jam mulai dan & Selasa,31 Maret 2009, 1 Hari, \\
& akhir) & mulai Pukul 09.00 s/d 17.30 WIB \\
9 & Jumlah Peserta & 282 Orang \\
10 & Jumlah peserta menurut gender (laki-laki dan & Laki-laki 250 orang; \\
& Perempuan) & perempuan 32 orang \\
\hline 11 & Jumlah peserta menurut pemerintah dan non & Pemerintah 240 orang; \\
& pemerintah & Non pemerintah 42 orang \\
\hline
\end{tabular}

Sumber : Kepmendagri Nomor 050-187/ Kep/Banda/2007 tentang pedoman penilaian dan Evaluasi Pelaksanaan Penyelenggaraan Musyawarah Perencanaan Pembangunan (Musrenbang), di Olah, 2012.

Bagian tersebut diatas ditujukan untuk mendapatkan atas ditujukan untuknt mendapatkan gambaran umum tentang kondisi Kabupaten Aceh Utara, status perkembangan perencanaan daerah, pengorganisasian dan profil peserta Musrenbang, terutama keikutsertaan kaum perempuan dan non gavernment stakeholders.

Jika melihat pada tahap persiapan dapat disimpulkan bahwa persiapan yang baik akan meningkatkan kualitas pelaksanaan dan hasil Musrenbang. Sasaran yang harus dicapai dalam persiapan Musrenbang adalah : (1) Peserta telah diberitahu lebih awal akan adanya Musrenbang; (2) Peserta telah menerima bahan yang akan dibahas sehingga memungkinkan peserta mempunyai cukup waktu untuk memahami tentang maksud dan tujuan Musrenbang, kemudian mengkaji, menyiapkan komentar, saran dan usulan yang terarah; (3) Informasi yang disajikan sesederhana mungkin sehingga mudah dipahami oleh peserta yang terdiri dari berbagai latar belakang pendidikan, pengalaman serta status sosial. 
Penilaian terhadap tahap persiapan mulai dari pengorganisasian penyelenggara, proses musyawarah sebelum Musrenbang sampai dengan ketersediaan informasi bagi peserta, dapat dilihat pada tabel berikut:

Tabel 3.2. Penilaian Tahap Persiapan Musrenbang Kabupaten Aceh Utara

\begin{tabular}{cccc}
\hline \multirow{2}{*}{ No } & Kegiatan & \multicolumn{2}{c}{ Realisasi } \\
\cline { 3 - 4 } & 2 & YA $\begin{array}{c}\text { Tida } \\
\mathrm{k}\end{array}$ \\
\hline 1 & 2 & 3 & 4
\end{tabular}

PERSIAPAN

A.1 Pengorganisasian Penyelenggaraan

1 Ada undangan jadwal dan agenda Musrenbang Kabupaten diumumkan/disampaikan mnimal 7 hari sebelum pelaksanaan

2 Media yang digunakan untuk mengumumkan undangan, jadwal dan agenda Musrenbang dinilai efektif

A.2 Proses Musyawarah yang mengawali musrenbang Kabupaten

3 Seluruh desa dan kelurahan telah melaksanakan Musrenbang Desa/kelurahan

4 Seluruh Desa/ kelurahan membuat nota kesepakatan hasil musrenbang desa/kelurahan

5 Seluruh kecamatan telah melaksanakan musrenbang kecamatan

6 Seluruh Kecamatan membuat nota kesepakatan musrenbangcam

7 Seluruh SKPD telah melaksanakan pembahasan Forum SKPD Lanjutan

8 Seluruh SKPD telah membuat Nota Kesepakatan hasil pembahasan forum SKPD

A.3 Ketersediaan Informasi bagi Peserta

9 Ada ringkasan pokok-pokok substansi RPJMD

10 Ada ringkasan rancangan RKPD tahun rencana yang disusun

Bappeda

11 Ringkasan Rancangan RKPD memuat: Program menurut fungsi, urusan wajib dan urusan pilihan

12 Kegiatan menurut fungsi, urusan wajib, dan urusan pilihan

13 Tolok ukur kinerja program dan kegiatan

14 Target kinerja capaian program dan kegiatan

15 Pagu indikatif program dan kegiatan

16 Ada ringkasan APBD tahun berjalan

17 Ada ringkasan Rancangan Renja-SKPD hasil Forum SKPD

18 Ringkasan Rancangan Renja SKPD memuat Program dan Kegiatan Internal SKPD

19 Ringkasan Rancangan Renja SKPD memuat Program dan kegiatan lintas SKPD

20 Rinkasan Rancangan Renja SKPD memuat Program dan kegiatan Lintas Kewilayahan

21 Ringkasan Rancangan Renja SKPD memuat program dan kegiatan Multi Tahun

22 Ada informasi tentang prioritas dan plafon anggaran alokasi dana desa 
23 Ada daftar prioritas kegiatan pembangunan di wilayah kecamatan yang

merupakan hasil Musrenbang Kecamatan

\author{
Jumlah Skor A.3 \\ Jumlah Skor Komponen A
}

Sumber: Kepmendagri Nomor 050-187/Kep/Bangda/2007/ Tahun 2007 tentang pedoman penilaian dan Evaluasi Pelaksanaan Penyelenggaraan Musyawarah Perencanaan Pembangunan (Musrenbang), Diolah, 2013

Dalam Musrenbang tingkat kabupaten, peserta yang hadir cukup banyak dan hampir semua unsur terwakili, terutama instansi pemerintahan terkait. Tingginya antusiasme wakil instansi pemerintah dalam menghadiri forum musrenbang disebabkan antara lain oleh keinginan untuk memperjuangkan usulan kegiatan yang terkait dengan dinas bersangkutan. Kehadiran wakil masyarakat dalam forum tersebut tidak terlalu lama dan tidak sampai pada acara akhir acara musrenbang.

Partisipasi masyarakat merupakan bagian yang tak terpisahkan dari pembangunan itu sendiri, sehingga nantinya seluruh lapisan masyarakat akan memperoleh hak dan kekuatuan yang sama untuk menuntut atau mendapatkan bagian yang adil dari manfaat pembangunan. Dengan demikian partisipasi masyarakat dalam musrenbang mutlak harus ada. Keterlibatan para pelaku pembangunan bisa secara langsung dan tidak langsung.

Ada dua sistem komunikasi yang berlangsung dalam pembangunan, yaitu: pertama, arus komunikasi vertikal (dari atas) yang bersumber dari perencana pembangunan maupun pejabat daerah setempat. Kedua, komunikasi horizontal yang berlangsung di antara anggota masyarakat. Komunikasi horizontal banyak dipengaruhi oleh komunikasi vertikal, sehingga komunikasi horizontal merupakan komunikasi tahap kedua (secondary flow) setelah berlangsungnya komunikasi vertikal.

Berdasarkan teori yang dikemukakan Wilson dan Rosenfeld bahwa komunikasi antara pemrakarsa perubahan dan pihak lain yang memegang peranan harus dilakukan secara intensif. Kepercayaan masyarakat akan menjadi rendah dan salah interpretasi akan mudah muncul apa bila komunikasi lemah. Oleh karena itu untuk mengelola perubahan dibutuhkan upaya yang keras demi menjamin lancarnya komunikasi yang efektif antara agen perubahan (agent of change) dengan berbagai pihak yang mampu mengkonsolidasikan perubahan tersebut.

Musyawarah perencanaan pembangunan telah menjadi istilah populer dalam penyelenggaraan perencanaan pembangunan dan penganggaran di daerah dan desa/kelurahan, namun pada pelaksanaannya, musrenbang seringkali belum mencerminan komunikasi, dialog yang efektif. Ini terlihat salah satu dari termaginalnya kepentingan masyarakat miskin, kaum perempuan terhadap penetapan prioritas program dalam pembangunan. Intervensi komunikasi dan politik terjadi dikarenakan seluruh elemen masyarakat belum mampu memahami demokrasi dan semangat pembangunan.

\title{
4. DAFTAR PUSTAKA
}

Depdiknas, Kamus Besar Bahasa Indonesia, 2000. Depdiknas, Jakarta

Hafied Cangara, Pengantar Ilmu Komunikasi. Jakarta: RajaGrafindo Persada, 2004

Kholil, Syukur. 2007. Komunikasi Islam. Bandung: Citapustaka Media

Muhammad Nasib ar-Rifa'i, Ringkasan Tafsir Ibnu Katsir, Jakarta: Gema Insani, 2007.

M. Tata Taufik, Etika Komunikasi Islam, Bandung: Pustaka Setia, 2012. 
Ujang Saefullah, Kapita Selekta Komunikasi-Pendekatan Budaya dan Agama, Bandung: Refika Offset, 2013.

http://bebas-blog.blogspot.com/2011/03/tabayyun-dan-urgensinya.html 